\title{
Characterization of a Thermotolerant Phytase Produced by Rhizopus microsporus var. microsporus Biofilm on an Inert Support Using Sugarcane Bagasse as Carbon Source
}

\author{
Vanessa Sayuri Sato ${ }^{1}$ - João Atílio Jorge ${ }^{2}$. \\ Luis Henrique Souza Guimarães ${ }^{1,2}$
}

Received: 15 October 2015 / Accepted: 15 February 2016 /

Published online: 23 February 2016

(C) Springer Science+Business Media New York 2016

\begin{abstract}
The Rhizopus microsporus var. microsporus biofilm was able to produce increased levels of an extracellular thermotolerant phytase using polyethylene and viscose as an inert support in both modified NBRIP medium and modified Khanna medium containing sugarcane bagasse as the carbon source. The enzyme production was strictly regulated by the phosphorus content with optimal production at $0.5 \mathrm{mM}$ of sodium phytate and $\mathrm{KH}_{2} \mathrm{PO}_{4}$. The extracellular phytase, RMPhy1, was purified 4.18-fold with $4.78 \%$ recovery using DEAE-cellulose and CM-cellulose. A single protein band with a molecular mass of $35.4 \mathrm{kDa}$ was obtained when the samples were subjected to $10 \%$ SDS-PAGE. The optimum temperature for activity was $55^{\circ} \mathrm{C}$ and the optimum $\mathrm{pH}$ was 4.5. $R$. microsporus var. microsporus phytase exhibited high stability at 30 and $40{ }^{\circ} \mathrm{C}$ with a half-life of $115 \mathrm{~min}$ at $60^{\circ} \mathrm{C}$. The enzyme activity increased in the presence of $\mathrm{Ca}^{2+}$ and was inhibited by $\mathrm{Zn}^{2+}$, arsenate, and sodium phosphate. Phytase demonstrated high substrate specificity for sodium phytate with $K_{\mathrm{m}}=0.72 \mathrm{mM}$ and $V_{\max }=94.55 \mathrm{U} / \mathrm{mg}$ of protein and for $p$-NPP with $K_{\mathrm{m}}=0.04 \mathrm{mM}$ and $V_{\max }=106.38 \mathrm{U} / \mathrm{mg}$ of protein. The enzyme also hydrolyzed ATP, AMPc, glucose 6-phosphate, glucose 1-phosphate, and UDPG. This is the first report on phytase characterization delivered with biofilm technology. The properties of the enzyme account for its high potential for use in biotechnology and the possibility of application in different industrial sectors as feed in the future.
\end{abstract}

Keywords Enzyme characterization $\cdot$ Fungal biofilm $\cdot$ Phytase $\cdot$ Rhizopus microsporus

Luis Henrique Souza Guimarães

lhguimaraes@ffclrp.usp.br

1 Institute of Chemistry of Araraquara, UNESP, Rua Francisco Degni s/n, 14800-900 Araraquara, São Paulo, Brazil

2 Faculty of Philosophy, Sciences and Letters of Ribeirão Preto, USP, Avenida Bandeirantes 3900, Monte Alegre, 14040-901 Ribeirão Preto, São Paulo, Brazil 


\section{Introduction}

Phosphate is a vital nutrient required in large amounts in order to maintain optimum levels of key cell molecules necessary for growth, division, and cellular metabolism, such as ATP, nucleic acids, and phospholipids; phosphorus is also a pivotal mediator in the regulation of many metabolic processes $[1,2]$. The main form in which phosphorus is stored in plants is in the phytate form, for example, in cereal and legumes, which are the major components of commercial animal feeds. However, phytate cannot be fully hydrolyzed by the digestive tract of monogastric animals. In addition, phytate is an important antinutritional agent able to complex with cations such as $\mathrm{Ca}^{2+}, \mathrm{Zn}^{2+}, \mathrm{Mn}^{2+}, \mathrm{Fe}^{2+}, \mathrm{Cu}^{2+}$, and $\mathrm{Mg}^{2+}$ as well as with proteins, thus reducing the bioavailability of these nutrients [3].

Phytases (myo-inositol hexakisphosphate phosphohydrolases) are enzymes that compose a special class of phosphatases. Phytases catalyze the hydrolysis of the phosphomonoester bonds of phytate (salts of myo-inositol 1,2,3,4,5,6-hexakis dihydrogen phosphate), releasing lower forms of myo-inositol and inorganic phosphates. On the basis of the site at which phytate dephosphorization begins, phytases can be grouped into three classes: 3-phytases (EC 3.1.3.8), 6-phytases (EC 3.1.3.26), and 5-phytases (EC 3.1.3.72). The fungal phytases are included in the 3-phytases class, in which the dephosphorization starts at the third phosphate group. Because of their catalytic mechanism, the fungal phytases belong to the histidine acid phosphatase class [3].

Phytases show great potential for application in different sectors such as in animal nutrition, human nutrition, aquaculture, and pharmacology. These enzymes are considered as a green feed additive that can be used to neutralize the antinutritional effects of phytate, thereby increasing the bioavailability of phosphorus and other minerals. They also contribute to the reduction of environmental pollution by phosphorus [4, 5]. Some isomers of myo-inositol phosphates have interesting pharmacological properties such as anti-inflammatory, antiangiogenic, and antitumor effects. The numbers and position of the phosphate residues in the myo-inositol ring are determinative for the effect of each myo-inositol isomer [6].

Microorganisms are the main source of phytases with biotechnological characteristics, and the enzymes used in the feed industry are mesophilic or thermophilic. Kinetic characterization of phytases from different sources indicated that the microbial enzymes are about 100,000 times more effective than those obtained from other sources [7]. In this context, filamentous fungi can be highlighted as important producers of phytases with interesting biotechnological characteristics such as thermal stability. Some fungal phytases have been characterized as those obtained from Rhodotorula mucilaginosa [4], Aspergillus niger [5], Paecilomyces variotii [8], Aspergillus caespitosus [9], Rhizopus oligosporus [10], and Aspergillus flavus [11].

Phytases can be produced using both submerged fermentation (SmF) and solid-state fermentation (SSF) [12]. However, new alternatives for the production of microbial enzymes have been used such as via the use of fungal biofilms, which is an innovative way of cultivating filamentous fungi. Fermentation conducted with fungal biofilm accounts for a homogenous system of production under the liquid environment, similar to $\mathrm{SmF}$, but with the efficiency of SSF [13]. Biofilms can be developed on polymeric matrices in a way that allows high structural organization of the organisms that are important in the production process [14]. Sato et al. [15] reported the production of phytases using the Rhizopus microsporus var. microsporus biofilm. The crude extract containing phytase was spray-dried and some properties of the dried product obtained were evaluated. However, the purification and characterization of $R$. microsporus var. microsporus phytases were not reported. Enzyme 
characterization is an important factor for determining its potential in commercial application. Therefore, in this study, we aimed to describe the production of an extracellular thermotolerant phytase by R. microsporus var. microsporus biofilm as well as its purification and biochemical characterization.

\section{Material and Methods}

\section{Microorganism and Culture Condition}

The filamentous fungus $R$. microsporus var. microsporus was isolated from Brazilian soil; identified at the Laboratory of Microbiology from the Federal University of Pernambuco, Brazil; and deposited in the Laboratory of Microbiology of the Faculdade de Filosofia, Ciências e Letras de Ribeirão Preto from the University of São Paulo, Brazil. The microorganism was maintained on slants of PDA medium (Acumedia, Lansing, MI, USA) at $30{ }^{\circ} \mathrm{C}$ for 7 days and then stored at $4{ }^{\circ} \mathrm{C}$.

The $R$. microsporus var. microsporus biofilms were developed initially on polyethylene inert supports $(2.0 \times 2.0 \mathrm{~cm})$, previously washed with detergent and distilled water, and then sterilized under UV radiation. For spore adhesion, the sterilized supports were immersed in aqueous spore suspension $\left(10^{6}\right.$ spores $\left./ \mathrm{mL}\right)$ at $30^{\circ} \mathrm{C}$ under agitation $(40-80 \mathrm{rpm})$ for $2 \mathrm{~h}$. Then, the supports were rinsed twice with distilled water for 30 min under agitation $(50 \mathrm{rpm})$ in order to remove the unadhered spores. The supports with adhered spores were transferred to $250 \mathrm{~mL}$ Erlenmeyer flasks containing $50 \mathrm{~mL}$ of different culture media: modified Khanna [16], Czapeck [17], Vogel [18], Segato-Rizzatti (SR) [19], and modified National Botanical Research Institute's phosphate growth medium (NBRIP) [20]. Different agro-industrial byproducts $(2.0 \% \mathrm{w} / \mathrm{v})$ (soya mince, rye flower, sugarcane bagasse, wheat bran, and orange peel) and saccharides $(2.0 \% \mathrm{w} / \mathrm{v})$ (fructose, galactose, glucose, maltose, and sucrose) were used as carbon sources, and the initial $\mathrm{pH}$ was adjusted to 6.0 . The media were previously autoclaved at $121{ }^{\circ} \mathrm{C}, 1.5 \mathrm{~atm}$ for $30 \mathrm{~min}$. The cultures were maintained at $30{ }^{\circ} \mathrm{C}$ under agitation ( $50 \mathrm{rpm}$ ) for $48 \mathrm{~h}$. The values from the media obtained were compared using Tukey's test with $p$ value fixed at 0.05 .

\section{Influence of Different Inert Supports on Biofilm Formation}

Different inert supports (TNT-100\% polypropylene, polyurethane foam, nylon, viscose, polyester, ethylene vinyl acetate (EVA), and polyethylene) were used for $R$. microsporus var. microsporus biofilm formation. For this purpose, the cells were cultured on modified NBRIP medium using sugarcane bagasse as carbon source $(20 \mathrm{~g} / \mathrm{L})$ under agitation $(50 \mathrm{rpm})$ at $30{ }^{\circ} \mathrm{C}$ for $48 \mathrm{~h}$.

\section{Influence of $\mathrm{KH}_{2} \mathrm{PO}_{4}$ and Sodium Phytate Upon Phytase Production}

Phytase production by $R$. microsporus var. microsporus biofilm was analyzed using modified NBRIP medium and modified Khanna medium added with different concentrations of sodium phytate $\left(\operatorname{Sigma}^{\circledR}\right)(0-20 \mathrm{mM})$ with sugarcane bagasse $(2 \% \mathrm{w} / \mathrm{v})$ as carbon source, initial $\mathrm{pH}$ 6.0. Additionally, the influence of different $\mathrm{KH}_{2} \mathrm{PO}_{4}$ concentrations $(0.1$ to $20 \mathrm{mM})$ added to modified Khanna medium upon enzyme production was also analyzed. 


\section{Determination of $p$-Nitrophenylphosphatase Activity}

The $p$-nitrophenylphosphatase activity was determined discontinuously using $1 \mathrm{mM} p$-nitrophenyl phosphate ( $p$-NPP) as substrate in $100 \mathrm{mM}$ sodium acetate buffer $\mathrm{pH} 5.0$ at $45^{\circ} \mathrm{C}$. The reaction was stopped by adding $2.0 \mathrm{~mL}$ saturated solution of sodium tetraborate at different time intervals. The $p$-nitrophenol released was determined using a spectrophotometer at $420 \mathrm{~nm}$. One unit of enzyme activity (U) was defined as the amount of enzyme required to release $1 \mu \mathrm{mol}$ of $p$-nitrophenol per min under the assay conditions. The specific activity was expressed as units per milligram of protein.

\section{Determination of Phytase Activity}

The phytase activity was assayed according to the method described by Gulati et al. [21] with some modifications. The reaction mixture was composed of $50 \mu \mathrm{L}$ of the enzyme sample and $50 \mu \mathrm{L}$ of $1 \%(w / v)$ sodium phytate (dodecasodium salt; Sigma) in $0.2 \mathrm{M}$ sodium acetate buffer $\mathrm{pH} 4.5$. After $30 \mathrm{~min}$, the reaction was stopped by the addition of $100 \mu \mathrm{L}$ of $15 \%$ trichloroacetic acid (TCA) at room temperature, and $300 \mu \mathrm{L}$ of distilled water was added to each test tube. Thereafter, $900 \mu \mathrm{L}$ of the chromogenic reagent (0.76 M sulfuric acid, $10 \%$ ascorbic acid, and 2.5\% ammonium molybdate; 3:1:0.5 $(v / v / v))$ was added and the tubes were incubated at $50{ }^{\circ} \mathrm{C}$ for $20 \mathrm{~min}$. The absorbance was read at $820 \mathrm{~nm}$. Controls without the addition of the enzyme were included for the estimation of nonenzymatic hydrolysis of the substrate. One unit of enzyme activity was defined as the amount of enzyme that releases $1 \mu \mathrm{mol}$ of inorganic phosphate per min under the assay conditions. The specific activity was expressed as units per milligram of protein.

\section{Protein Quantification}

The protein content was quantified according to Bradford [22] using bovine serum albumin (BSA) as the standard and expressed as milligram of protein.

\section{Purification of Phytase Produced by R. microsporus var. microsporus Biofilms}

After incubation as described above, the biofilm was removed from the medium containing sugarcane bagasse as the carbon source using a sterile tweezer, and the free cell liquid containing the extracellular enzyme was dialyzed overnight at $4{ }^{\circ} \mathrm{C}$ against distilled water and loaded in DEAE-cellulose chromatographic column $(1 \times 12 \mathrm{~cm})$ equilibrated with $50 \mathrm{mM}$ sodium acetate buffer, $\mathrm{pH}$ 5.0. Fractions of $3 \mathrm{~mL}$ were collected at a flow rate of $1 \mathrm{~mL}$ per min using a linear gradient of $\mathrm{NaCl}(0-1 \mathrm{M})$. Fractions with $p$-nitrophenylphosphatase activity were monitored and two enzyme peaks with phytase activity were obtained. Peak I (RMPhy1), which did not interact with DEAE-cellulose resin, was loaded in the chromatographic column $(1 \times 8 \mathrm{~cm})$ of CM-cellulose equilibrated with $50 \mathrm{mM}$ sodium acetate buffer, $\mathrm{pH}$ 5.0. Fractions of $3 \mathrm{~mL}$ were collected at a flow rate of $0.5 \mathrm{~mL}$ per min using a linear gradient of $\mathrm{NaCl}$ $(0-1 \mathrm{M})$ in the same buffer. Fractions with phytase activity were pooled, dialyzed overnight at $4{ }^{\circ} \mathrm{C}$, and concentrated using a $30-\mathrm{kDa}$ cutoff Amicon membrane (Millipore) at $8000 \mathrm{~g}$ for $15 \mathrm{~min}$ at $4{ }^{\circ} \mathrm{C}$. The concentrated fraction was used for the electrophoresis procedure and enzyme characterization. 


\section{Electrophoresis}

The purified sample was applied to polyacrylamide gel electrophoresis under denaturing conditions (SDS-PAGE $10 \%$ ) [23], using a power source adjusted to $120 \mathrm{~V}$ and $40 \mathrm{~mA}$. After running, the gels obtained were stained using Coomassie Brilliant Blue-R250. For SDSPAGE, the Precision Plus Protein Standards Kaleidoscope $\left(\right.$ Bio-Rad $\left.^{\circledR}\right)$ was used as molecular weight markers (10-250 kDa).

\section{Characterization of RMPhy1 Phytase}

The effect of temperature $\left(30-80{ }^{\circ} \mathrm{C}\right)$ and $\mathrm{pH}(100 \mathrm{mM}$ sodium acetate buffer $\mathrm{pH} 3.5$ to 6.0 ; $100 \mathrm{mM}$ Ampol buffer $\mathrm{pH} 6.0$ to $7.0 ; 100 \mathrm{mM}$ Tris-HCl buffer $\mathrm{pH} 7.0$ to 10.0 ) on phytase activity was determined.

The thermal stability analysis was performed by maintaining the enzymatic samples at different temperatures $\left(30-70{ }^{\circ} \mathrm{C}\right)$ for $120 \mathrm{~min}$. At different time periods, samples were withdrawn and maintained in an ice bath for subsequent measurement of enzyme activity. The $\mathrm{pH}$ stability was determined in the $\mathrm{pH}$ range of 3.5 to 10.0 using the same buffer solutions cited above for 30 and $60 \mathrm{~min}$ at room temperature $\left(29^{\circ} \mathrm{C}\right)$.

\section{Effect of Different Compounds on Enzyme Activity}

The effects of 1 and $2 \mathrm{mM}$ of $\mathrm{KCl}, \mathrm{MgCl}_{2}, \mathrm{ZnSO}_{4}, \mathrm{CuCl}_{2}, \mathrm{CoCl}_{2}$, and $\mathrm{CaCl}_{2} ; 0.2$ and $0.4 \mathrm{mM}$ of $\mathrm{FeSO}_{4} ; 5$ and $10 \mathrm{mM}$ of EDTA; 0.25 and $1 \mathrm{mM}$ of sodium arsenate; and 1 and $5 \mathrm{mM}$ of potassium phosphate on enzyme activity were analyzed. The reactions were carried out in a $100 \mathrm{mM}$ acetate buffer at $\mathrm{pH} 4.5$ containing $1 \%$ sodium phytate as substrate. Residual activity was calculated by considering the value obtained during the absence of compounds as $100 \%$.

\section{Hydrolysis of Substrates and Estimation of Kinetic Parameters}

The ability of the enzyme to hydrolyze sodium phytate (1 mM), $p$-NPP $(2 \mathrm{mM})$, ATP ( $2 \mathrm{mM})$, AMPc $(0.5 \mathrm{mM})$, uridine diphosphate glucose (UDPG) $(2.5 \mathrm{mM})$, and glucose 6-phosphate and glucose 1-phosphate (both at $2 \mathrm{mM}$ ) was analyzed under the same conditions described for sodium phytate. The kinetic parameters $V_{\max }, K_{\mathrm{m}}$, and $V_{\max } / K_{\mathrm{m}}$ were estimated using sodium phytate as the substrate $(0.01$ to $4 \mathrm{mM})$ and $p$-NPP $(0.01$ to $5 \mathrm{mM})$, as described above. The calculation and graphical representation were fit using the OriginPro 8.0 software according to Lineweaver-Burk [24].

\section{Results and Discussion}

\section{Formation of $\boldsymbol{R}$. microsporus var. microsporus Biofilm}

The level of agitation during the process of biofilm formation, and consequently, in enzyme production, is an important aspect that should be considered. Initially, the R. microsporus var. microsporus biofilms were developed in Khanna medium using sugarcane bagasse as the carbon source, as previously reported [15], and $0.5 \mathrm{mM}$ of $\mathrm{KH}_{2} \mathrm{PO}_{4}$ was added. As seen in Table 1, the use of agitation from 40 to $60 \mathrm{rpm}$ allowed the formation of a biofilm without free 
cells in the culture medium, indicating greater resistance of the $R$. microsporus var. microsporus biofilm structure. The biomass of the biofilm during each condition was similar. However, when 70- and 80-rpm stirrings were used, the biomass of the biofilm that adhered to the support decreased ( 0.90 and $0.35 \mathrm{~g}$, respectively), and free biomass was observed in the culture medium, indicating a minor resistance of biofilms under these conditions of agitation. High level of agitation can promote de-adhesion of the spores of the inert support leading to the free mycelium formation.

Therefore, fungal morphology and, consequently, the enzyme production can be affected by the culture conditions; under SmF, the fungal growth can vary between the pelleted and filamentous forms. The orientation of growth in both $\mathrm{SmF}$ and biofilm fermentation (BF) systems is different; pellets increase in density rather than depth under SmF, while the opposite is observed for BF [13]. However, specific aspects of the relation between enzyme production and fungal morphology under BF need to be investigated in the future.

\section{Effect of Different Concentrations of $\mathrm{KH}_{2} \mathrm{PO}_{4}$ on Phytase Production}

In order to improve the production of extracellular phytase by $R$. microsporus var. microsporus biofilms, the effect of different concentrations of $\mathrm{KH}_{2} \mathrm{PO}_{4}(0-5 \mathrm{mM})$ added to modified Khanna medium (without yeast extract) was analyzed. Maximum phytase production (Fig. 1) was observed at $0.5 \mathrm{mM} \mathrm{KH_{2 }} \mathrm{PO}_{4}(61.6 \mathrm{U} / \mathrm{mg}$ of protein) and maintained without significant differences at high $\mathrm{KH}_{2} \mathrm{PO}_{4}$ concentrations. On the other hand, the specific activity of the enzyme decreased above $0.5 \mathrm{mM} \mathrm{KH}_{2} \mathrm{PO}_{4}$. These results indicate that phytase production by $R$. microsporus var. microsporus biofilm is stimulated by the phosphorus source in the medium, suggesting that there is a link between the use of exogenous phosphate, mobilization of reserves, and enzymatic production. Similar results were obtained for phytases and other microbial phosphatases $[25,26]$. The regulation of enzymatic synthesis by $\mathrm{Pi}$ is coordinated by the PHO pathway that has been reported for different organisms, including fungi. In Saccharomyces cerevisiae, high $\mathrm{Pi}$ levels are responsible for the activation of a cyclin-dependent kinase complex that phosphorylates the positive regulator Pho4 (encoded by the $\mathrm{PHO} 4$ gene), which remains in the cytoplasm. However, at low Pi levels, the unphosphorylated Pho4 travels to the nucleus and activates the $\mathrm{PHO}$ gene transcription allowing the secretion of the acid phosphatases and other proteins related to the Pi uptake [27].

\section{Production of Phytase by $R$. microsporus var. microsporus Biofilm Using Different Culture Media}

Table 2 shows the production of phytase by R. microsporus var. microsporus biofilms as the function of different culture media added with $0.5 \mathrm{mM} \mathrm{K \textrm {K } _ { 2 }} \mathrm{PO}_{4}$. The maximum phytase

Table 1 Influence of agitation in the formation of $R$. microsporus var. microsporus biofilms

\begin{tabular}{lll}
\hline Agitation (rpm) & Biofilm biomass (g) & Free biomass (g) \\
\hline 40 & 2.15 & - \\
50 & 2.48 & - \\
60 & 2.10 & - \\
70 & 0.90 & 0.39 \\
80 & 0.35 & 0.16 \\
\hline
\end{tabular}


Fig. 1 Phytase production by $R$. microsporus var. microsporus biofilms at different concentrations of $\mathrm{KH}_{2} \mathrm{PO}_{4}$

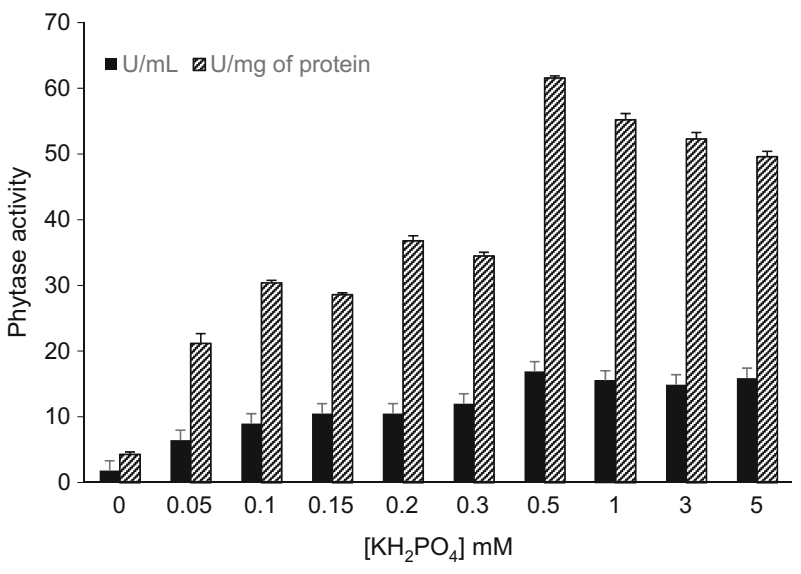

production was detected in modified NBRIP medium (without the addition of glucose) (69.9 U/mg protein) followed by modified Khanna medium (without yeast extract) (46.3 U/ mg protein). Production using modified NBRIP medium was 20 -fold higher than that observed using SR medium. NBRIP medium has been used in the search and selection of phosphatesolubilizing microorganisms [28]. In addition, the result obtained for modified NBRIP medium was 1.5-fold higher than that observed for the modified Khanna medium used previously.

\section{Influence of Different Inert Supports Upon Biofilm Formation and Phytase Production}

Considering the high enzymatic production obtained when using modified NBRIP medium, the biofilm formation using different inert supports was analyzed (Table 3). The supports were selected on the basis of availability, low cost, homogeneous distribution of particle size, and surface roughness (this provides a larger surface area for adhesion of microorganisms). All supports were colonized by $R$. microsporus var. microsporus with good spore adhesion and biofilm formation. Couto et al. [29] stated that filamentous fungi have a great affinity for inorganic and organic surfaces; however, the adhesion mechanisms are not yet understood well. Different materials have been reported for use as fungal adhesion materials such as synthetic foams (polyurethane), nylon sponge, geotextile webs of polyamide, and polyester cloth [14, 29, 30]. Thus, as seen in Table 2, a higher level of phytase production was observed when viscose $(169.61 \mathrm{U} / \mathrm{mg})$ and polyethylene $(163.0 \mathrm{U} / \mathrm{mg})$ were used as supports, and the specific enzyme activities were also highest (3-folds higher) for these compared to the use of

Table 2 Phytase production by $R$. microsporus var. microsporus biofilms in different culture media

The cultures were maintained under agitation $(50 \mathrm{rpm})$ at $30^{\circ} \mathrm{C}$ for $48 \mathrm{~h}$

\begin{tabular}{ll}
\hline Medium & U/mg protein \\
\hline Modified Khanna & 46.3 \\
Czapeck & 8.79 \\
Vogel & 11.5 \\
M5 & 15.7 \\
SR & 3.41 \\
Modified NBRIP & 69.9
\end{tabular}


Table 3 Phytase production by $R$. microsporus var. microsporus biofilms obtained on different supports using modified NBRIP medium

The cultures containing sugarcane bagasse were maintained at $30{ }^{\circ} \mathrm{C}$ for $48 \mathrm{~h}$ at $50 \mathrm{rpm}$

\begin{tabular}{lr}
\hline Supports & U/mg protein \\
\hline TNT & $138.5 \pm 0.20$ \\
Polyurethane foam & $71.6 \pm 0.67$ \\
Nylon & $79.5 \pm 0.80$ \\
Viscose & $169.61 \pm 0.70$ \\
Polyester & $128.0 \pm 0.80$ \\
Polyethylene & $163.0 \pm 0.20$ \\
EVA & $53.3 \pm 0.67$ \\
\hline
\end{tabular}

EVA as a support. The choice of inert support for fungal adhesion and biofilm formation is essential in designing an effective system for particular purposes.

\section{Effect of Different Concentrations of Sodium Phytate on Phytase Production}

The addition of $0.5 \mathrm{mM}$ sodium phytate in both modified Khanna medium and modified NBRIP medium increased phytase production 2.6-fold and 1.4-fold, respectively, as compared to the absence of phytate condition (Fig. 2). At this concentration, enzymatic production using modified NBRIP medium was 4-fold higher than that obtained when using modified Khanna medium. However, at high phytate concentration $(20 \mathrm{mM})$, the production was reduced for both media used. These results indicate that the expression of $R$. microsporus var. microsporus phytase can be regulated by the phytate concentration in the culture medium.

\section{Purification and Molecular Mass Determination}

The chromatographic profile by loading crude filtrate obtained in modified NBRIP medium onto DEAE-cellulose is presented in Fig. 3a. Two enzymatic peaks (I and II) were obtained. Peak I (RMPhy1) does not interact with the resin, while peak II (RMPhy2) was eluted with $0.25 \mathrm{M} \mathrm{NaCl}$ using a linear gradient $(0-1 \mathrm{M})$. Both pooled peaks presented phytase activity. After dialysis, the RMPhy1 pool was loaded onto the CM-cellulose chromatographic column and eluted with $0.5 \mathrm{M} \mathrm{NaCl}$ (Fig. 3b). Different approaches have been used for the purification of microbial phytases such as precipitation using acetone followed by Macro-prep high Qcolumn and ultrafiltration used for A. flavus ITCC 6720 phytase [11] and ammonium sulfate precipitation, ion exchange chromatography, and gel filtration chromatography for Bacillus licheniformis PFBL-03 phytase [31].

The phytase RMPhy1 was purified 4.18-fold with a $4.78 \%$ yield (Table 4 ). This yield was better as compared to the values obtained for the purified phytase from A. flavus ITCC 6720 [11] and two purified isoforms of intracellular phytase from $R$. oligosporus after five steps of purification with a recovery of $1.3-1.6 \%$ [10].

A single protein band of $35.4 \pm 2.6 \mathrm{kDa}$ was obtained under SDS-PAGE for RMPhy1 (Fig. 4, lane D). This molecular mass value was close to that found for Cladosporium sp. FP-1 phytase (32.6 kDa) [32] and for A. niger 307 phytase (39 kDa) [33]. According to Yao et al. [34], phytases are proteins with highly variable molecular mass, ranging from 40 to $500 \mathrm{kDa}$. The phytases from $A$. niger commercialized by La Roche and BASF have molecular masses of 89.14 and $65.73 \mathrm{kDa}$, respectively [35]. The phytases produced by $R$. oligosporus showed a molecular mass of $45 \mathrm{kDa}$ [10]. The efficiency of each purification step, i.e., DEAE-cellulose 


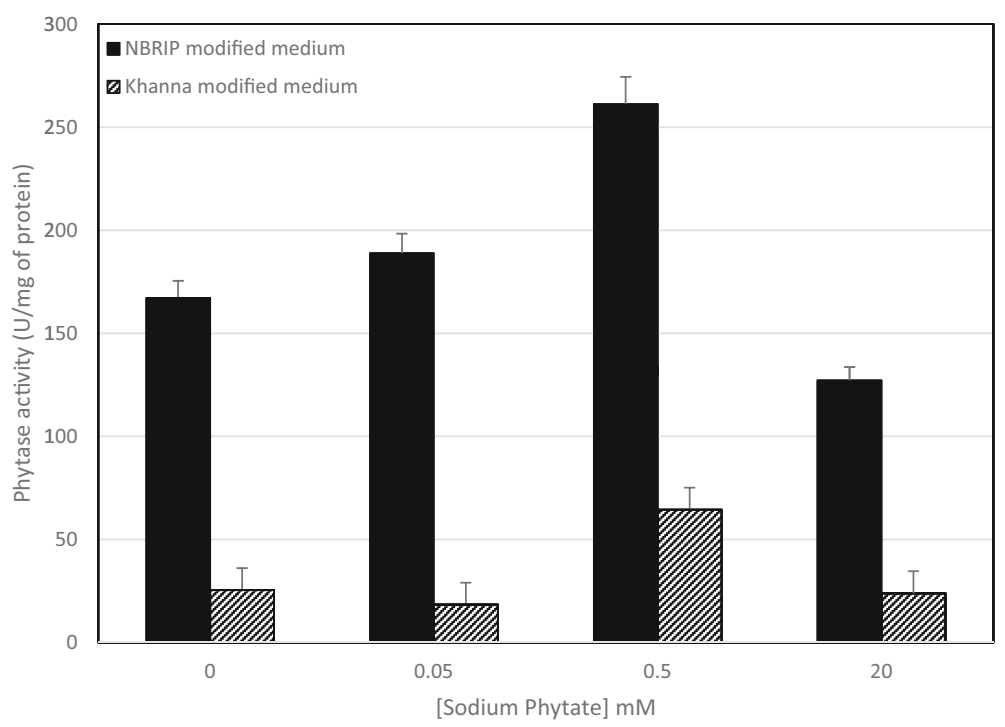

Fig. 2 Phytase production by $R$. microsporus var. microsporus biofilms at different concentrations of sodium phytate added to the modified NBRIP and modified Khanna media

(Fig. 4, lane B), CM-cellulose (Fig. 4, lane C), and after filtration through a 30-kDa cutoff membrane (Fig. 4, lane D), also can be observed, with significant reduction of the amount of contaminant proteins.

\section{Influence of pH and Temperature Upon RMPhy1 Phytase Activity}

The influence of temperature and $\mathrm{pH}$ on the activity of the enzyme is an important characteristic that needs to be considered before its possible biotechnological application. Figure 5 shows that the optimum activity for phytase produced by $R$. microsporus var. microsporus biofilm was achieved at $\mathrm{pH} 4.5$ and $55^{\circ} \mathrm{C}$. Most phytases present optimum enzyme activity at a $\mathrm{pH}$ range from 4.0 to 6.0 for that produced by A. niger ( $\mathrm{pH} 5.0-5.5)$, A. fumigatus $(\mathrm{pH} 4.0$ 6.0), and Peniophora lycii (pH 4.0-5.0), among others [3]. RMPhy1 phytase was able to act
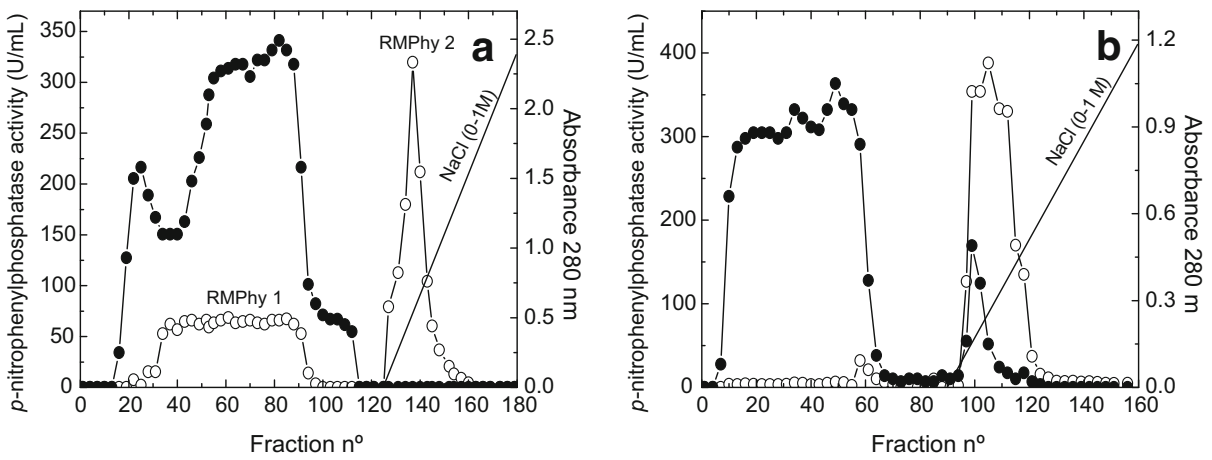

Fig. 3 Chromatographic profiles of DEAE-cellulose (a) and CM-cellulose (b) for the phytases produced by R. microsporus var. microsporus biofilms in modified NBRIP medium using sugarcane bagasse as carbon source. Symbols: filled circle, absorbance $280 \mathrm{~nm}$; empty circle, $p$-nitrophenylphosphatase activity 
Table 4 Purification of the phytase RMPhy1 produced by R. microsporus var. microsporus biofilms

\begin{tabular}{lllllll}
\hline Step & $\begin{array}{l}\text { Volume } \\
(\mathrm{mL})\end{array}$ & $\begin{array}{l}\text { Activity } \\
(\mathrm{U})\end{array}$ & $\begin{array}{l}\text { Total } \\
\text { protein } \\
(\mathrm{mg})\end{array}$ & $\begin{array}{l}\text { Specific } \\
\text { activity (U/ } \\
\text { mg) }\end{array}$ & $\begin{array}{l}\text { Yield } \\
(\%)\end{array}$ & $\begin{array}{l}\text { Purification } \\
\text { (fold) }\end{array}$ \\
\hline Crude extract & 180 & 9546.0 & 17.5 & 545.5 & 100 & 1 \\
DEAE-cellulose & 95 & 2098.5 & 8.3 & 252.8 & 22.0 & 0.5 \\
CM-cellulose & 25 & 457.0 & 0.2 & 2285.0 & 4.78 & 4.18 \\
\hline
\end{tabular}

under alkaline conditions ( $\mathrm{pH} 8-10.5)$ maintaining $65-75 \%$ of its activity. This characteristic is very interesting because there is no report on a fungal phytase acting at an alkaline $\mathrm{pH}$ for the genus Rhizopus. Until now, only a phytase produced by A. niger ATCC 9142 was described as acting under alkaline $\mathrm{pH}$ conditions [36]. Studies have also investigated the optimum temperature for phytase activity in the range from 40 to $70{ }^{\circ} \mathrm{C}$ [34]. Despite maximal activity observed at $55{ }^{\circ} \mathrm{C}$, the RMPhyl phytase maintained 85 and $73 \%$ of its activity at 60 and $65{ }^{\circ} \mathrm{C}$, respectively. The activity from Cladosporium sp. FP-1 phytase was optimum at $40{ }^{\circ} \mathrm{C}$, while the phytases from Aspergillus oryzae [37] and B. licheniformis PFBL-03 [31] showed optimum activity at $55^{\circ} \mathrm{C}$.

The RMPhy 1 phytase produced by $R$. microsporus var. microsporus biofilms was stable at 30 and $40{ }^{\circ} \mathrm{C}$ for $120 \mathrm{~min}$, maintaining $80-95 \%$ of its activity (Fig. $5 \mathrm{~d}$ ). At $60{ }^{\circ} \mathrm{C}$, the $R$. microsporus var. microsporus phytase showed a half-life $\left(t_{50}\right)$ of $115 \mathrm{~min}$, which was better than that observed for the Escherichia coli phytase that maintained only $24 \%$ of its activity at $60{ }^{\circ} \mathrm{C}$ for $1 \mathrm{~h} \mathrm{[38]}$ and better than that observed for $R h$. mucilaginosa phytase with a half-life of

Fig. 4 Ten percent SDS-PAGE for purified RMPhyl phytase produced by $R$. microsporus var. microsporus biofilms stained with Coomassie Brilliant Blue-R250. Lane $A$ molecular weight markers, $B$ peak I (RMPhy1) obtained from DEAE-cellulose, $C$ phytase containing fraction after CM-cellulose, $D$ phytase containing fraction after filtration through a 30-kDa membrane (Amicon, Millipore). For details, see "Material and Methods" section
$150 \mathrm{kDa}$

$75 \mathrm{kDa}$

$50 \mathrm{kDa}$

$37 \mathrm{kDa}$

$25 \mathrm{kDa}$

$20 \mathrm{kDa}$

$15 \mathrm{kDa}$

$10 \mathrm{kDa}$ 

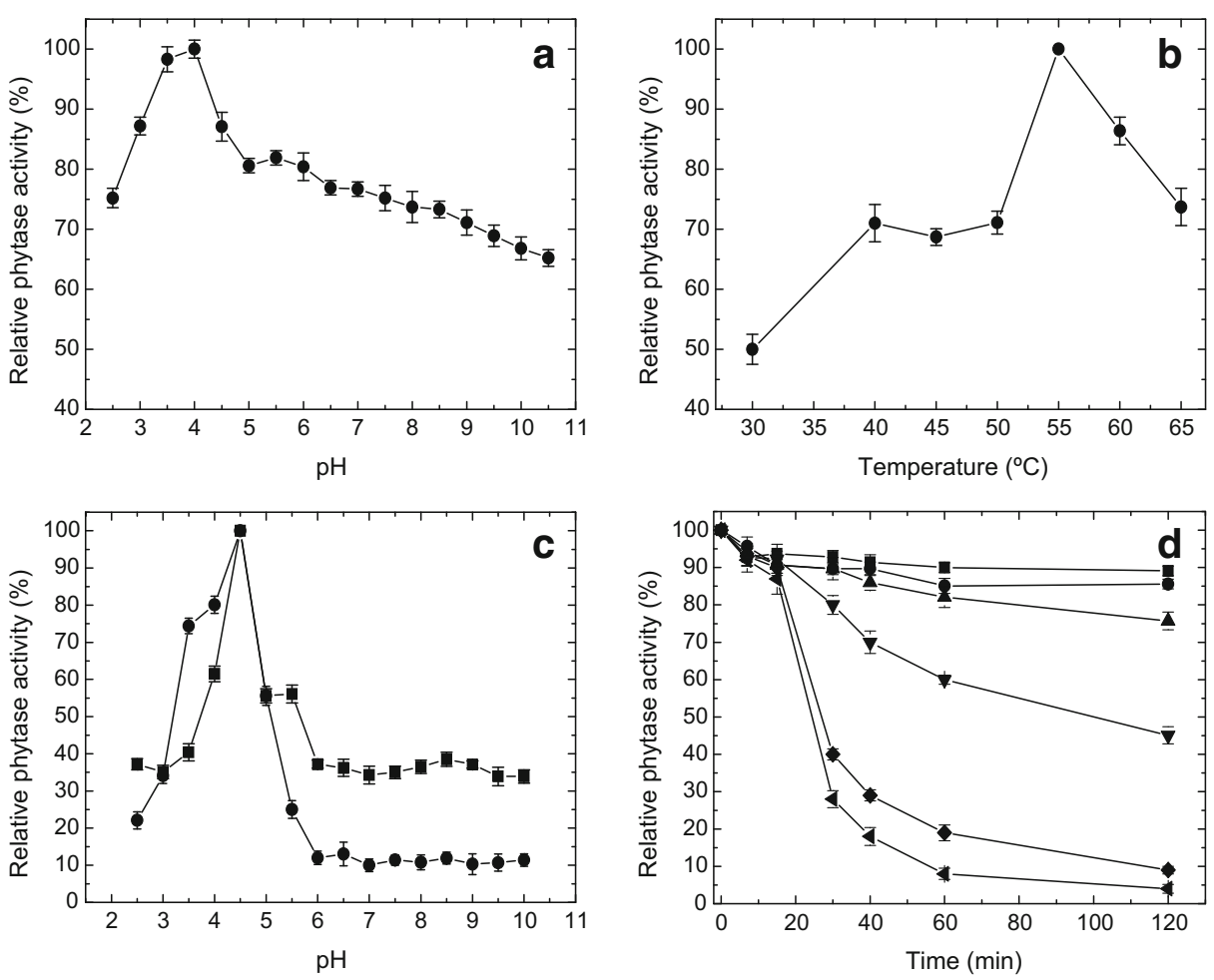

Fig. 5 Determination of optimum of $\mathrm{pH}(\mathbf{a})$, temperature (b), and $\mathrm{pH}$ stability (c) for 30 (filled square) and $60 \mathrm{~min}$ (filled circle), and thermal stability (d) at $30^{\circ} \mathrm{C}$ (filled square), $40^{\circ} \mathrm{C}$ (filled circle), $50^{\circ} \mathrm{C}$ (filled triangle), $60{ }^{\circ} \mathrm{C}$ (filled inverted triangle), $65^{\circ} \mathrm{C}$ (filled diamond), and $70^{\circ} \mathrm{C}$ (filled left-pointing arrowhead) for RMPhy 1 phytase produced by $R$. microsporus var. microsporus biofilms

$10 \mathrm{~min}$ at $60{ }^{\circ} \mathrm{C}$ [4]. At 65 and $70^{\circ} \mathrm{C}$, the half-life was $28-31 \mathrm{~min}$, higher than that observed for the phytase produced by Rh. mucilaginosa [4]. Thermostability is an important characteristic for preserving the nutrition of the animal feed because the enzyme needs to resist the temperature of pelletization [3].

The $R$. microsporus var. microsporus RMPhy1 phytase maintained $75-100 \%$ of its activity in the $\mathrm{pH}$ range from 3.5 to 4.5 for both 30 and $60 \mathrm{~min}$ of incubation (Fig. $5 \mathrm{c}$ ). The phytase activity from Bacillus nealsonii ZJ0702 decreased dramatically at a $\mathrm{pH}$ of 4.0 with incubation for $30 \mathrm{~min}$ [39], while the A. niger NCIM 563 phytase showed broad pH stability from 2.0 to 9.0 [40].

\section{Effect of Different Compounds Upon RMPhy1 Phytase Activity}

Table 5 displays the influence of different compounds, such as ions and chelating agents, on RMPhy1 phytase activity. $R$. microsporus var microsporus phytase activity was significantly affected primarily by $\mathrm{Ca}^{2+}(+24-42 \%)$; this was also observed for the enzymes produced by A. flavus ITCC 6720 [11] and A. niger [41]. On the other hand, phytase RMPhyl activity reduced in the presence of $\mathrm{K}^{+}, \mathrm{Zn}^{2+}, \mathrm{Cu}^{2+}$, and $\mathrm{Co}^{2+}$. This inhibitory effect could be due to the formation of poorly soluble complexes of the metal ions with phytate, which can reduce the concentration of phytate available for hydrolysis in the assay [42]. Inhibition of enzyme activity by $\mathrm{Cu}^{2+}$ and $\mathrm{Zn}^{2+}$ was also observed for $A$. niger phytase [41], while the enzyme 
produced by Schizophyllum commune was activated in the presence of $\mathrm{CuSO}_{4}$ and $\mathrm{ZnSO}_{4}$ [43]. Ions can interact with charged amino acids on the protein surface or in its active site, promoting conformational modifications that can positively or negatively affect the enzyme activity.

R. microsporus var. microsporus phytase RMPhy1 was not affected by ethylenediaminetetraacetic acid (EDTA), suggesting that it is not a metalloenzyme. EDTA, a chelating compound, can form a complex with various important metal ions, negatively affecting the catalytic activity of enzymes, as reported for the enzyme produced by Mucor indicus [44]. On the other hand, EDTA can also stimulate phytase activity, as reported for the enzyme produced by $A$. fumigatus [7].

Phosphate and arsenate can be considered as potent inhibitors of $R$. microsporus var. microsporus phytase RMPhyl activity. Arsenate is a structural analog of phosphate and it is assumed that its inhibiting action is because of its linking to the catalytic site of the enzyme. Pi is a product obtained via the action of phytase and it is a specific inhibitor of enzyme activity [45]. Pi can act through a competitive inhibition model. Inhibition of the phytase RMPhy1 activity by sodium phosphate suggests that the concentration of inorganic phosphate regulates not only enzyme synthesis and induction but also enzymatic activity.

\section{Hydrolysis of Substrates and Kinetic Parameters}

Phytase RMPhyl was able to hydrolyze not only sodium phytate and $p$-NPP but also all other substrates used (Table 6). The enzymatic activity in the presence of sodium phytate was higher than that obtained for the use of ATP, AMPc, UDPG, glucose 6-phosphate, and glucose 1phosphate. On the other hand, the enzyme activity using $p$-NPP as substrate was $33 \%$ higher

Table 5 Effect of different compounds on RMPhy1 phytase activity from $R$. microsporus var. microsporus biofilm

\begin{tabular}{|c|c|c|}
\hline \multirow[t]{2}{*}{ Compounds } & \multicolumn{2}{|c|}{ Relative phytase activity (\%) } \\
\hline & $1 \mathrm{mM}$ & $2 \mathrm{mM}$ \\
\hline Control & 100 & 100 \\
\hline $\mathrm{KCl}$ & $60.20 \pm 0.33$ & $49.69 \pm 0.12$ \\
\hline $\mathrm{MgCl}_{2}$ & $102.82 \pm 0.44$ & $108.46 \pm 0.13$ \\
\hline $\mathrm{ZnSO}_{4}$ & $60.12 \pm 0.89$ & $15.38 \pm 0.35$ \\
\hline $\mathrm{CuCl}_{2}$ & $95.24 \pm 0.66$ & $88.46 \pm 0.33$ \\
\hline $\mathrm{CoCl}_{2}$ & $98.32 \pm 0.28$ & $54.60 \pm 0.88$ \\
\hline \multirow[t]{2}{*}{$\mathrm{CaCl}_{2}$} & $124.4 \pm 0.44$ & $142.92 \pm 0.42$ \\
\hline & $0.2 \mathrm{mM}$ & $0.4 \mathrm{mM}$ \\
\hline \multirow[t]{2}{*}{$\mathrm{FeSO}_{4}$} & $99.45 \pm 0.66$ & $109.80 \pm 0.62$ \\
\hline & $5 \mathrm{mM}$ & $10 \mathrm{mM}$ \\
\hline \multirow[t]{2}{*}{ EDTA } & $98.34 \pm 0.48$ & $96.92 \pm 0.88$ \\
\hline & $0.25 \mathrm{mM}$ & $1 \mathrm{mM}$ \\
\hline \multirow[t]{2}{*}{ Sodium arsenate } & 0.93 & 0.84 \\
\hline & $1 \mathrm{mM}$ & $5 \mathrm{mM}$ \\
\hline Potassium phosphate & 0.03 & 0.00 \\
\hline
\end{tabular}

Phytase activity $100 \% ; 161.69 \mathrm{U} / \mathrm{mg}$ protein 
Table 6 Hydrolysis of different substrates using the purified enzyme produced by $R$. microsporus var. microsporus

\begin{tabular}{lll}
\hline Substrates & Specific activity (U/mg of protein) & Relative activity (\%) \\
\hline Sodium phytate $(1 \mathrm{mM})$ & 78.27 & 100 \\
$p$-NPP $(2 \mathrm{mM})$ & 104.82 & 133.92 \\
ATP $(2 \mathrm{mM})$ & 37.47 & 47.87 \\
AMPc $(0.5 \mathrm{mM})$ & 55.63 & 71.07 \\
UDPG $(2.5 \mathrm{mM})$ & 13.10 & 16.74 \\
Glucose 6-phosphate $(2 \mathrm{mM})$ & 57.70 & 73.72 \\
Glucose 1-phosphate $(2 \mathrm{mM})$ & 18.73 & 23.93 \\
\hline
\end{tabular}

Enzymatic sample obtained after filtration through the 30-kDa membrane

than that observed for sodium phytate. Additionally, it is possible to observe that the enzyme has preference to hydrolyze the phosphate located in carbon 6 in the molecule of glucose. Phytase produced by $M$. indicus hydrolyzed sodium phytate, $p$-NPP, ATP, and AMP as well [44]. The kinetic parameters $K_{\mathrm{m}}$ and $V_{\max }$ were estimated as $0.72 \mathrm{mM}$ and $94.55 \mathrm{U} / \mathrm{mg}$ of protein for the hydrolysis of sodium phytate and as $0.04 \mathrm{mM}$ and $106.38 \mathrm{U} / \mathrm{mg}$ of protein for $p$-NPP by phytase RMPhyl produced by $R$. microsporus var. microsporus biofilms. This shows higher affinity demonstrated by the synthetic substrate than that by the natural one. The value obtained for the relation $V_{\max } / K_{\mathrm{m}}$ was 131.32 and $2659.5 \mathrm{U} / \mathrm{mg}$ of protein $\mathrm{mM}^{-1}$ for sodium phytate and $p$-NPP, respectively. The $K_{\mathrm{m}}$ value obtained using sodium phytate was lower than that reported for A. niger NCIM 563 phytase PhyI (2.01 mM) [40], for A. niger $\left(K_{\mathrm{m}}\right.$ $0.92 \mathrm{mM}$ ) [33], and for $R$. oligosporus phytase RO1 (1.6 mM) [10], indicating that the enzyme from $R$. microsporus var. microsporus has more affinity toward this substrate than these enzymes. On the other hand, the $K_{\mathrm{m}}$ value was higher than that observed for phytase RO2 $(0.13 \mathrm{mM})$ from $R$. oligosporus [10] and the phytases produced by $S$. commune $(0.16 \mathrm{mM})$ [43] and Rh. mucilaginosa JMUY14 (0.24 mM) [4].

\section{Conclusion}

Biofilm fermentation can be used effectively to produce high levels of phytase via $R$. microsporus var. microsporus with a high potential for use in biotechnology, as demonstrated by its high thermal and acidic $\mathrm{pH}$ tolerance; its ability to hydrolyze different natural substrates, especially sodium phytate; and the effect of ions on reducing its activity. The effect of temperature on enzyme activity can also be considered an interesting characteristic for its biotechnological application. In addition, we demonstrated that phytase production and activity are regulated by phosphate. This is the first description of the characterization of fungal phytase produced using biofilm technology. Phytase produced by $R$. microsporus var. microsporus shows good potential for future industrial applications, and its use in animal feed may be emphasized.

Acknowledgments We thank Fundação de Amparo à Pesquisa do Estado de São Paulo (FAPESP-Process no. 2011/50880-1) and CAPES (Coordenação de Aperfeiçoamento de Pessoal do Ensino Superior) for the financial support and Maurício de Oliveira for the technical assistance. This manuscript is part of the VSS Ph.D. thesis presented to the Institute of Chemistry of Araraquara-UNESP, Araraquara, São Paulo, Brazil. 


\section{References}

1. Vance, C. P., Uhde-Stone, C., \& Allan, D. L. (2003). Phosphorus acquisition and use: critical adaptations by plants for securing a nonrenewable resource. New Phytologist, 157, 423-447.

2. Yang, X. J., \& Finnegan, P. M. (2010). Regulation of phosphate starvation responses in higher plants. Annals of Botany, 105, 513-526.

3. Rao, D. E. C. S., Rao, K. V., Reddy, T. P., \& Reddy, V. D. (2009). Molecular characterization, physicochemical properties, known and potential applications of phytases: an overview. Critical Reviews in Biotechnology, 29, 182-198.

4. Yu, P., Wang, X.-T., \& Liu, J.-W. (2015). Purification and characterization of a novel cold-adapted phytase from Rhodotorula mucilaginosa strain JMUY14 isolated from Antarctic. Journal of Basic Microbiology, 54, 1-11.

5. Greiner, R., Silva, L. G., \& Couri, S. (2009). Purification and characterization of an extracellular phytase from Aspergillus niger 11T53A9. Brazilian Journal of Microbiology, 40, 795-807.

6. Hurrel, R. F., Reddy, M. B., Juillerat, M. A., \& Cook, J. D. (2003). Degradation of phytic acid in cereal porridges improves iron absorption by human subjects. The American Journal of Clinical Nutrition, 77, 1213-1219.

7. Wyss, M., Brugger, R., Kronenberger, A., Rémy, R., Fimbel, R., Oesterhelt, G., Lehmann, M., \& van Loon, A. P. G. M. (1999). Biochemical characterization of fungal phytases (myo-inositol hexakisphosphate phosphohydrolases): catalytic properties. Applied and Environment Microbiology, 65, 367-373.

8. Jr, M., Macedo, J. A., \& Macedo, G. A. (2011). A new process for simultaneous production of tannase and phytase by Paecilomyces variotii in solid-state fermentation of orange pomace. Bioprocess and Biosystems Engineering. doi:10.1007/s00449-011-0587-y.

9. Guimarães, L. H. S., Terenzi, H. F., Jorge, J. A., \& Polizeli, M. L. T. M. (2004). Characterization and properties of acid phosphatase with phytase activity produced by Aspergillus caespitosus. Biotechnology and Applied Biochemistry, 39, 1-7.

10. Azeke, M. A., Greiner, R., \& Jany, K.-D. (2011). Purification and characterization of two intracellular phytases from the tempeh fungus Rhizopus oligosporus. Journal of Food Biochemistry, 35, 213-227.

11. Gaind, S., \& Singh, S. (2015). Production, purification and characterization of neutral phytase from thermotolerant Aspergillus flavus ITCC 6720. International Biodeterioration \& Biodegradation, 99, 15-22.

12. Shivanna, G.B., \& Venkateswaran, G. (2014). Phytase production by Aspergillus niger CFR335 and Aspergillus ficuum SGA01 through submerged and solid-state fermentation. Scientific World Journal, article ID $392615,1-6$.

13. Gutiérrez-Correa, M., Ludeña, Y., Ramage, G., \& Villena, G. K. (2012). Recent advances on filamentous fungal biofilms for industrial uses. Applied Biochemistry and Biotechnology, 167, 1235-1253.

14. Gamarra, N. N., Villena, G. K., \& Gutierrez-Correa, M. (2010). Cellulase production by Aspergillus niger in biofilm, solid-state, and submerged fermentations. Applied Microbiology and Biotechnology, 87, 545-551.

15. Sato, V. S., Jorge, J. A., Oliveira, W. P., Souza, C. R. F., \& Guimarães, L. H. S. (2014). Phytase production by Rhizopus microsporus var. microsporus biofilm: characterization of enzymatic activity after spray drying in presence of carbohydrates and nonconventional adjuvants. Journal of Microbiology and Biotechnology, 24, $177-187$.

16. Khanna, P., Sundari, S. S., \& Kumar, N. J. (1995). Production, isolation and partial-purification of xylanases from an Aspergillus sp. World Journal of Microbiology and Biotechnology, 11, 242-243.

17. Wiseman, A. (1975). Handbook of enzyme biotechnology (p. 148). Chichester: Wiley.

18. Vogel, H. J. (1964). Distribution of lysine pathways among fungi-evolutionary implications. American Naturalist, 98, 435-446.

19. Rizzatti, A. C. S., Jorge, J. A., Terenzi, H. F., Rechia, C. G. V., \& Polizeli, M. L. T. M. (2001). Purification and properties of a thermostable extracellular $\beta$-D-xylosidase produced by the thermotolerant Aspergillus phoenicis. Journal of Industrial Microbiology and Biotechnology, 26, 156-160.

20. Nautiyal, C. S. (1999). An efficient microbiological growth medium for screening phosphate solubilizing microorganisms. FEMS Microbiology Letters, 170, 265-270.

21. Gulati, H. K., Chadha, B. S., \& Saini, H. S. (2007). Production and characterization of thermostable alkaline phytase from Bacillus laevolacticus isolated from rhizosphere soil. Journal of Industrial Microbiology and Biotechnology, 34, 91-98.

22. Bradford, M. M. (1976). Rapid and sensitive method for quantitation of microgram quantities of protein utilizing principle of protein-dye binding. Analytical Biochemistry, 72, 248-254.

23. Laemmli, U. K. (1970). Cleavage of structural proteins during the assembly of the head of bacteriophage T4. Nature, 227, 680-685.

24. Lineweaver, H., \& Burk, D. (1934). The determination of enzyme dissociation constants. Journal of the American Chemical Society, 56, 658-666. 
25. Vohra, A., \& Satyanarayana, T. (2003). Phytases: microbial sources, production, purification, and potential biotechnological applications. Critical Reviews in Biotechnology, 23, 29-60.

26. Kneipp, L. F., Rodrigues, M. L., Holandino, C., Esteves, F. F., Souto-Padrón, T., Alviano, C. S., Travassos, L. R., \& Meyer-Fernandes, J. R. (2004). Ectophosphatase activity in conidial forms of Fonsecaea pedrosoi is modulated by exogenous phosphate and influences fungal adhesion to mammalian cells. Microbiology-Sgm, $150,3355-3362$.

27. Dick, C.F., Dos-Santos, A.L.A., \& Meyer-Fernandes, J.R. (2011). Inorganic phosphate as na important regulator of phosphatases. Enzyme Research, article ID 103980, 1-7.

28. Zhu, X.-L., Zhang, L. H., An, L., Gao, X., \& Wang, Y. (2014). Plant growth promoting activities of phosphate-solubilizing bacteria Acinetobacter calcoaceticus YC-5a and Enterobacter agglomerans KMC-7. Journal of Pure and Applied Microbiology, 8, 2613-2618.

29. Couto, S. R., Sanromán, M. A., Hofer, D., \& Gübitz, G. M. (2004). Stainless steel sponge: a novel carrier for the immobilization of the white-rot fungus Trametes hirsuta for decolourization of textile dyes. Bioresource Technology, 95, 67-72.

30. Villena, G. K., \& Gutierrez-Correa, M. (2006). Production of cellulase by Aspergillus niger biofilms developed on polyester cloth. Letters in Applied Microbiology, 43, 262-268.

31. Fasimoye, F. O., Olajuyigbe, F. M., \& Sanni, M. D. (2014). Purification and characterization of a thermostable extracellular phytase from Bacillus licheniformis PFBL-03. Preparative Biochemistry and Biotechnology, 44, 193-205.

32. Quan, C. S., Tian, W. J., Fan, S. D., \& Kikuchi, J. (2004). Purification and properties of a low-molecularweight phytase from Cladosporium sp. FP-1. Journal of Bioscience and Bioengineering, 97, 260-266.

33. Sariyska, M. V., Gargova, S. A., Koleva, L. A., \& Angelov, A. I. (2005). Aspergillus niger phytase: purification and characterization. Biotechnology and Biotechnological Equipment, 19, 98-105.

34. Yao, M. Z., Zhang, Y. H., Lu, W. L., Hu, M. Q., Wang, W., \& Liang, A. H. (2012). Phytases: crystal structures, protein engineering and potential biotechnological applications. Journal of Applied Microbiology, $112,1-14$.

35. Yin, Q. Q., Zheng, Q. H., \& Kang, X. T. (2007). Biochemical characteristics of phytases from fungi and the transformed microorganism. Animal Feed Science and Technology, 132, 341-350.

36. Casey, A., \& Walsh, G. (2003). Purification and characterization of extracellular phytase from Aspergillus niger ATCC 9142. Bioresource Technology, 86, 183-188.

37. Uchida, H., Rakidaa, S., Skamotob, T., \& Kawasakib, H. (2006). Expression of Aspergillus oryzae phytase gene in Aspergillus oryzae RIB40 niaD(-). Journal of Bioscience and Bioengineering, 102, 564-567.

38. Greiner, R., Konietzny, U., \& Jany, K. D. (1993). Purification and characterization of 2 phytases from Escherichia coli. Archives of Biochemistry and Biophysics, 303, 107-113.

39. Yu, P., \& Chen, Y. (2013). Purification and characterization of a novel neutral and heat-tolerant phytase from a newly isolated strain Bacillus nealsonii ZJ0702. BMC Biotechnology, 13, 78. doi:10.1186/1472-6750-13-78.

40. Soni, S. K., Magdum, A., \& Khire, J. M. (2010). Purification and characterization of two distinct acidic phytases with broad $\mathrm{pH}$ stability from Aspergillus niger NCIM 563. World Journal of Microbiology and Biotechnology, 26, 2009-2018.

41. Dvorakova, J., Volfova, O., \& Kopecky, J. (1997). Characterization of phytase produced by Aspergillus niger. Folia Microbiologica, 42, 349-352.

42. Wang, H. L., Swain, E. W., \& Hesseltine, C. W. (1980). Phytase of molds used in oriental food fermentation. Journal of Food Science, 45, 1262-1266.

43. Salmon, D. N., Piva, L. C., Binati, R. L., Rodrigues, C., Vandenberghe, L. P., Soccol, C. R., \& Spier, M. R. (2012). A bioprocess for the production of phytase from Schizophyllum commune: studies of its optimization, profile of fermentation parameters, characterization and stability. Bioprocess Biosystems Engineering, 35, 1067-1079.

44. Gulati, H. K., Chadha, B. S., \& Saini, H. S. (2007). Production of feed enzymes (phytase and plant cell wall hydrolyzing enzymes) by Mucor indicus MTCC 6333: purification and characterization of phytase. Folia Microbiologica, 52(5), 491-497.

45. Freitas-Mesquita, A. L., \& Meyer-Fernandes, J. R. (2014). Biochemical properties and possible roles of ectophosphatase activities in fungi. International Journal of Molecular Science, 15, 2289-2304. 